\title{
会報
}

九州歯科学会月例会報告

$$
3 \text { 月 例会 }
$$

平成 15 年 3 月 19 日（水）午後 1 時より

（九州歯科大学附属図書館視聴覚教室）

\section{演 題}

1. 唾液流出量の低下と口腔内揮発性硫化物

$$
\text { 九歯大·予 歯: 越宗紳二郎 }
$$

2. ホルマリン誘発疼痛反応に対するアデノシン $A_{1}$ 受 容体作動薬の影響

$$
\text { 九歯大·歯 麻: 山本秀一郎 }
$$

\section{3 月例会講演抄録}

\section{1．唾液流出量の低下と口腔内揮発性硫化物}

越宗紳二郎（九歯大·予 柬） 硫化水素やメチルメルカプタンなどの揮発性硫化物は口臭の主な原因物質であり, 舌や歯周の健康状態は, 口腔の 揮発性硫化物濃度に影響を与えることが知られている。一方, 唾液流出量の減少は, 口腔の自浄作用を低下させるこ とから，口臭発生に影響を与える一要因と考えられる。しかし，今のところ唾液流出量と口臭の関連について明確な 根拠は得られていない，本研究では唾液流出量の減少と口臭発生の関係を明らかにするため，唾液流出量と口腔内揮 発性硫化物濃度および口臭発生に関連する項目との関係について分析した。

九州歯科大学附属病院予防歯科·口臭外来を受診した患者のうち, 男性 52 名, 女性 122 名の計 174 名（平均年齢 $48.6 \pm 13.7$ 歳）を対象者とした。口腔内揮発性硫化物はガスクロマトグラフを用いて硫化水素抢よびメチルメルカプ タン濃度を測定した。唾液は吐唾法（安静時）ならびにパラフィン法（刺激時）によって採取した。スペアマン相関 分析の結果, 唾液流出量と口腔内揮発性硫化物濃度との間には有意な相関関係は認められなかったが, 安静時ならび に刺激時の唾液流出量によって対象を 2 群に分類し, 群間の比較を行った結果, 安静時唾液流出量が少ない群は, コ ントロール群と比較して, 有意に高い揮発性硫化物濃度ならびに舌苔スコアを示した。さらにロジスティック分析の 結果, 安静時唾液流出量の減少, 舌苔および歯周ポケット数の増加が口腔内揮発性硫化物の発生に強く関与する要因 であることが分かった。

本研究により舌や歯周の健康状態だけでなく, 安静時唾液流出量の減少が口臭発生に影響を与えていることが示唆 された。

\section{Low salivary flow and volatile sulfur compounds in mouth air}

Shinjiro Koshimune (Department of Preventive Dentistry, Kyushu Dental College)

The purpose of this study is to determine if a reduction of salivary flow will influence the production of methyl mercaptan $\left(\mathrm{CH}_{3} \mathrm{SH}\right)$ and hydrogen sulfide $\left(\mathrm{H}_{2} \mathrm{~S}\right)$, which are volatile sulfur compounds (VSCs) known to cause oral malodor. The VSCs in mouth air were measured using gas chromatography, and the salivary flow rates were determined using the spitting (resting) and the masticatory (stimulated) 
methods from 174 patients.

There was no significant correlation between the VSCs level and salivary flow rate. However, the subjects with extremely low resting salivary flow had significantly higher $\mathrm{CH}_{3} \mathrm{SH}$ and $\mathrm{H}_{2} \mathrm{~S}$ concentrations and tongue coating scores compared to subjects with higher resting salivary flow rates. Moreover, the logistic analyses showed that the extremely low resting salivary flow and the increase in the tongue coating and the probing pocket depth greater than $4 \mathrm{~mm}$ were the strong explanatory factors for the generation of the VSCs which could reflect oral malodor. The findings of the present study suggested that the extreme reduction of resting saliva influenced the generation of $\mathrm{CH}_{3} \mathrm{SH}$ and $\mathrm{H}_{2} \mathrm{~S}$ in mouth air.

\section{2. ホルマリン誘発疼痛反応に対するアデノシン $\mathrm{A}_{1}$ 受容体作動薬の影響}

山本秀一郎（九歯大·歯 麻）

アデノシン $\mathrm{A}_{1}$ 受容体作動薬 R-PIA 䯣腔内投与がホルマリン注射後のフリンチング行動と脊䯣グルタミン酸放出 にどの様な影響を及ぼすかについて評価した。その結果，R-PIA は濃度依存性にホルマリン注射後のフリンチング 行動の増加を抑制し，その作用はアデノシン $\mathrm{A}_{1} / \mathrm{A}_{2}$ 受容体拮抗薬アミノフィリンによって拮抗された。モルフィンは フリンチングを抑制したが，MK-801 は部分的にしか抑制しなかった，ホルマリン注射誘発の春咀道グルタミン酸放出 の増加はモルフィンによって抑制されたが R-PIA や MK-801では抑制されなかった．以上の事からアデノシン $\mathrm{A}_{1}$ 受容体作動薬はシナプス前におけるグルタミン酸放出を介さずにむしろシナプス後に抗侵害作用を発現する事が示唆 された.

\section{Intrathecal adenosine $A_{1}$ receptor agonist attenuates hyperalgesia without inhibiting spiral glutamate release in the rat \\ Syuichiro Yamamoto (Department of Dental Anesthesiology, Kyushu Dental College)}

The modulating effects of intrathecal adenosine $A_{1}$ receptor agonist, R-PIA, were evaluated on the flinching behavior and CSF-glutamate release after formalin injection into the rat paw. R-PIA significantly and dose-dependently attenuated increases in flinching behavior and this attenuating effect was reversed by the adenosine $A_{1} / A_{2}$ receptor antagonist, aminophylline. Morphine blocked flinchings, however MK-801 partially abolished. The increase in CSF-glutamate release evoked by formalin was inhibited by morphine but not by either R-PIA or MK-801. These findings suggest that the intrathecal adenosine $A_{1}$ receptor agonist provokes antinociceptive effect via the postsynaptic action independent of an effect upon spinal glutamate release. 